\title{
"Die Grenzen des Sagbaren": H. G. Adler (on) Writing Literature after the Holocaust
}

\author{
Traci S. O'Brien (1)
}

Citation: O’Brien, Traci S. 2021. “Die Grenzen des Sagbaren": H. G. Adler (on) Writing Literature after the Holocaust. Humanities 10: 63. https:/ / doi.org/10.3390/h10020063

Received: 28 January 2021

Accepted: 17 March 2021

Published: 31 March 2021

Publisher's Note: MDPI stays neutral with regard to jurisdictional claims in published maps and institutional affiliations.

Copyright: (C) 2021 by the author. Licensee MDPI, Basel, Switzerland. This article is an open access article distributed under the terms and conditions of the Creative Commons Attribution (CC BY) license (https:/ / creativecommons.org/licenses/by/ $4.0 /)$.
Department of Foreign Languages and Literatures, Auburn University, Auburn, AL 36849, USA; tso0001@auburn.edu

\begin{abstract}
Taking the next step in our understanding of the testimony of Holocaust literature involves taking a step back to recuperate a theoretical approach that does not cede all human attempts at knowledge to skepticism. At odds with Theodor Adorno about the possibility of writing poetry after Auschwitz, Adler, a survivor of Theresienstadt and Auschwitz, transformed his experiences into fiction. In his novel, Eine Reise, published in 1962, and in his 1965 essay on "Die Grenzen des Sagbaren," or the limits of the sayable, Adler addresses these dilemmas. While Adorno collapses traditions of value into barbarity, Adler struggles to maintain, describe and explain the possibility of human resistance to evil. I examine Adler's nuanced use of language in these two works and show that the rage and epistemological uncertainty that dominate the post-Holocaust world do not necessarily lead to the destruction of all traditional forms of meaning.
\end{abstract}

Keywords: Holocaust; literature; H. G. Adler; Adorno

\section{Introduction}

Taking the next step in our understanding of the testimony of Holocaust literature involves taking a step back to recuperate a theoretical approach that acknowledges the difficulty of human knowing but does not cede to epistemological impossibility all human attempts to know. In a similar manner to the disagreement between Theodor W. Adorno and H. G. Adler on this topic (J. Adler 2000), much of the theoretical response to the Holocaust fits into one of two categories of thought: Do we affirm or deny the existence of any human ideals?

At odds with Adorno and his dictum regarding the impossibility of writing poetry after Auschwitz (Adorno 1977, p. 30), Adler, a survivor of Theresienstadt and Auschwitz, transformed his experiences into poetry and fiction, as well as scholarly essays (for Adler's biography in English, see Filkins 2019). Highly productive, Adler wrote a trio of novels in the postwar period, now often referred to as the "Shoah trilogy" (e.g., Filkins 2016, p. 47). In the second of these, Eine Reise, published in 1962, and in English translation as The Journey in 2008, and in his 1965 essay on "Die Grenzen des Sagbaren," or the limits of the sayable, Adler compels the reader to think about how literature can work, what language can do, and how meaning is made. Adorno (1973) collapses culture and traditions of value into barbarity, for example, with his position that "Auschwitz demonstrated irrefutably that culture has failed" (p. 366) and that "all post-Auschwitz culture, including its urgent critique, is garbage" (p. 367). In contrast, Adler struggles to maintain, describe and explain the possibility of human resistance to overwhelming evil in the continuity of certain values and the possibility of a bridge of understanding through language. Adler demonstrates a richness and complexity of language that insists on meaning and contrasts with a "mechanical materialism," or an abstracted view of humanity, that facilitates the use of people as things (H. G. Adler 2017, p. 561). Adler shows that the rage and epistemological uncertainty that dominate the post-Holocaust world do not lead to the destruction of all traditional forms of meaning, they just make this meaning more difficult to find. 
Scholarship on H. G. Adler (1910-1988) has surged in the past decade and includes a monograph and two essay collections dedicated exclusively to Adler's oeuvre, two volumes that place Adler's work in conversation with other post-Holocaust authors, a biography, and dozens of individual book chapters and essays that focus on Adler's fiction and scholarly writing. In addition, the translation into English of his Shoah trilogy-The Journey (2008) was followed by Panorama (2011) and The Wall (2014) - has introduced him to a wider audience.

As is often noted, Adler decided early on during his experience in the camps that he was going to write about it. In a conversation near the end of his life, Adler explains:

When it came to the deportations, I told myself: I won't survive this. But if I do survive, I want to represent it, and in two different ways: I want to explore it in a scholarly manner and so separate it from myself completely, and I want to portray it in a literary manner. I have done both, and the fact that I have done so is no great achievement, but it does provide a small justification for having survived. This transformation of experience into literary work gave me an extraordinary power. (Schnelting 1987, p. 170; translated by J. Adler 2016, p. 25)

Adler was true to his word, leaving behind a breath-taking oeuvre that does, in fact, include essays, novels, poetry and short fiction, some of which are still lying unpublished in archives (Wolff 2019).

Prior to the re-release and translation of his Shoah trilogy, Adler was most famous for his work, Theresienstadt 1941-1945: Das Antlitz einer Zwangsgemeinschaft (1960), a nearly 900page comprehensive account of the camp, first published in 1955 and recently translated into English as Theresienstadt 1941-1945: The Face of a Coerced Community (2017). Many Adler scholars focus on this work as an anchor point in Adler's oeuvre. Krämer (2012) discusses it as vital to an interpretation of both Adler's scholarly and literary work because the experiences in Theresienstadt hover in the background of his fiction (see also Gwyer 2014; Menzel 2016). While documenting the camp's history, sociology, and psychology, Adler addresses the reader periodically throughout the work with questions regarding future action. For example, after describing the absolute void or "Nothing" that was Theresienstadt, Adler asks:

What must happen so that this end, which was Nothing, can still be followed by a beginning that would be Something? Only a few of the survivors, and even fewer of their contemporaries, have answered this. However, as long as this riddle is not satisfactorily solved, this essential question continues to exist for us and all posterity. (H. G. Adler 2017, p. 172)

To even begin to answer Adler's question is a daunting task. It requires understanding, to the degree possible, what happened, and that one be able to create "Something," that is, meaning. It also requires a modicum of faith in language and the possibility of moral action between human beings.

In what follows, I address Adler's appeal for a "Something" by investigating how Adler uses language to make meaning, that is, to restore the relationships between words, things, and, eventually, people. I will begin with an analysis of Adler's 1965 essay, "Die Grenzen des Sagbaren." As Wolff notes, though Adler does not mention his experiences in the camps in this essay specifically, "we can nevertheless read Adler's title as an anticipation of one of the central issues of Holocaust studies, namely the problem of representability" (Wolff 2016, p. 275). This essay also demonstrates Adler's faith in language and the possibility of a willing, engaged readership. While he investigates the limits of language, Adler also takes pains to define language as a system and a tool for communication between human beings. Furthermore, it is fruitful to read this essay in conjunction with Eine Reise (1999), because neither work makes mention by name the traumatic events that Adler personally witnessed and experienced, yet questions of representation and faith in meaning-making are at the center of both works, as is the affirmation of literature as a powerful tool in the process. There is also a stylistic correlation: Similar to the novel, the 
essay does not follow rules of linear or scientific logic and development. Both of these works use an associational strategy and challenge the reader to make connections and engage with difficult material.

\section{2. "Die Grenzen des Sagbaren," or the Limits of the Sayable}

In "Die Grenzen des Sagbaren" (1965), Adler questions the ability of language to express the full range of human experience. However, the limitations implied in the title are not absolute but rather products of the dynamic interplay between individuals and social convention. Despite the seeming pessimism of the title, this essay ultimately affirms human possibility in the face of limitation and the essay itself is written in a way that dramatizes dynamic communication and connection with the reader.

Adler begins the essay with the assertion that not everything that is communicable is also sayable, since human beings also communicate in gestures, facial expressions, and tone of voice (p. 97). At the same time, the sayable is defined as "communicable through language, either in speech or in writing" (p. 97). ${ }^{1}$ All unpublished translations used in this essay are my own.) Adler creates a constant tension throughout the essay between language as a tool for individual consciousness and individual ability and social conventions and the broad accord which they necessitate. However, expressible meaning is not simply enacted in a linear flow of statements but also by interrupting that flow to engage the reader in ideas that transcend a simple one-to-one correlation of words and consider human beings as "capable of and meant for autonomy" (H. G. Adler 2017, p. 560).

To approach the limits of the sayable, therefore, Adler lays out his points in an associational manner that requires his readers to think about how meaning is made in and through the act of putting things together in multiple ways. The very beginning of the essay demonstrates this strategy. While Adler spends most of the first paragraph moving through a series of logical steps to define language as a tool for human beings, he integrates poetic language to complicate those associations and suggest the richness of what can be created with language. Speech, according to Adler, is the root of real language though it has no lasting quality. Adler emphasizes this transitoriness: Speech "passes away immediately" (vergeht unmittelbar p. 97) and exists in the "realm" of things that "fade away into silence" (verklingender Bereich p. 97). In contrast, writing transforms speech into something we can own. Written forms of language have permanence and their development he describes as a "gain" or "profit" (Gewinn p. 97) and "possession" (Besitz p. 97), suggesting their static, and perhaps capitalistic, nature. Thus, going against the grain of linear progress, Adler contrasts poetic loss with static gain. However, he then ends the paragraph by stating that written language is, in the broadest sense, literature. In other words, rather than being simply a possession, written language has the literary quality of being representational and commemorative. Adler does not explain what he means by this but instead includes a quote from Goethe and the idea that great literature can sometimes say things that would otherwise remain difficult to express and rescue that which would fade away into silence.

Thus, part of what Adler is "saying" about the limits of the sayable inheres in his strategy of association. He states: "With our language, we do not say visible and invisible things or the relationships that operate between them, rather we mean these things with language, we denote and connote them through language" (H. G. Adler 1965, p. 98; translated by Wolff 2016, p. 274). According to Adler, everything that happens in language corresponds to certain things and relationships in our world and in ourselves (H. G. Adler 1965, p. 98). It is true that, when we open our mouths to speak, objects do not fall from our lips, so we are not actually "saying" anything. However, human beings do mean things with language, both objects in the world and relationships between them, that is, the in-between spaces where meaning also happens. The structure of the essay purposefully creates these spaces for readers.

1 Das Sagbare ist das durch die Sprache mitteilbare Gut, sei es durch die Rede mitteilbar oder durch die Schrift. All unpublished translations used in this essay are my own. Going forward, longer German original quotations will be in the footnotes. 
As the essay develops, Adler continues to explore both an understanding of language itself as well as its limits. He integrates ideas from multiple thinkers-for example, Locke, Leibniz, Steinthal, and Schleiermacher-in order to create a brief, but fascinating, narrative of the development of human understanding of language. Again, rather than developing his ideas in a purely linear fashion, Adler returns to his evolving concept of language multiple times throughout the essay. Language is a closed system of "signs" (Zeichen) that organizes communication (p. 97) and a conventional correlation of "phonograms" (Lautzeichen) that refer to what can be contained in the broad category of human experience (98). Language is thus a system of correlation, one that is conventional because it is a social phenomenon and requires agreement ( $p$. 98). This possibility of meaningful language allows human beings to understand each other (p. 99). Language is, in turn, the prerequisite for, and the decisive marker in the definition of, human society (p. 99).

Other thinkers, such as Hans Lipps, Herder, Jacob Grimm, Wilhelm von Humboldt, and Wittgenstein, help Adler define various limits of the sayable. The fact that the sayable does not include all the visible and audible markers that we give to speech to enhance its meaning, such as gesture and intonation, is a relatively innocuous limit. The first limit that describes a real impediment is the temporary "extinguishing of social abilities" (Verlöschen sozialer Fähigkeiten p. 98), which renders us speechless and unable to find a "bridge to a you" (Brücke zu einem Du p. 98) in language. Such moments occur due to intense negative emotions or sublime rapturous states. This temporary disappearance of one's "personness" (Persönlichkeit p. 98) or contact with another, however, is not regarded by Adler as a failing in itself. Instead, the real problems seem to result from a different category of unsayable which he calls an "inadequacy of social capacity" (Ungenügen des sozialen Vermögens p. 98), or a "failure of consciousness" (Unvermögen des Bewußtseins p. 99). Since language is abstract and correlational (p. 98), the limits of the sayable correspond to the extent to which we-both socially and individually-are able to establish this correlativity between words and the things or relationships they designate (p. 99). However, everything that is sayable does not always result in "conventionally comprehensible meaning" (konventionell auffaßbaren Sinn p. 101) —and the fact that it does at all, Adler states, is a miracle (p. 101).

Indeed, because language is made up of words that are both "units of meaning" and "radiating fields of meaning" (Sinneinheiten, ausstrahlende Sinnfelder p. 100), individuals may construct their own misunderstanding. Adler's phrase, "a bridge to a you," points to another important aspect of the sayable: Communicability also depends on the recipient of the communication. As Adler states and demonstrates with this essay, a message conveyed is not a static object that one person delivers to another but must be processed by the recipient (p. 99). The limits of the sayable are thus accompanied by the limits of the understandable, but neither is a fixed point as they depend on the communication as well as the specific people involved. These latter limits depend on the ability and willingness of individuals involved in the communication to understand, and this is a matter of character, psychology, and of one's own will (p. 102). In trying to explain and bridge this gap, Adler is suggesting that we have a responsibility to others, one that will be important for a reading of Eine Reise.

Adler evokes the Biblical tower of Babel, noting that every person in modern society is potentially a linguistic island unto themselves, whereby the sheer effort to communicate may not be enough (p. 101). Indeed, in the one such passage that reverberates with the emotion Adler surely felt at times, he describes the deep loneliness and isolation that results from not being understood or being purposefully misunderstood by those around us (pp. 101-2). Hence, even though "language [is] an uninterrupted attempt to overcome isolation and create a collective order," the hindrances ensure that, when two people say the same thing, it is not necessarily the same thing at all (p. 102). ${ }^{2}$ Finally, Adler notes the Wittgensteinian attempts to rescue propositions from doubt and instability and thus introduces the limits of linguistic precision into the equation (p. 102).

2 Die Sprache [ist] ein ununterbrochener Anlauf zur Überwindung der Einsamkeit und zum Erschaffen kollektiver Ordnung. 
Adler does not actually arrive at a clear and final definition of "the limits of the sayable" in this essay. The tension between language as a social convention and the individual ability to say and understand is not resolved. However, Adler's seemingly noncommittal strategy reveals an optimistic understanding of the role of language in human experience. He ends the essay with a quote by the German Romantic philosopher Krause that points beyond the ability of language to represent and commemorate but stays within the context of the human ability to see, both through eyesight and insight. Such sight "is before and above language; speaking, looked at from the point of view of seeing, is just an ability to see the sign and the signified together" (p. 103). ${ }^{3}$ Further, human thinking, knowing, and wanting are not exclusively bound up with language nor are they exhausted by language, but they are a prerequisite for language. Ending almost back where he began, Adler states, with Krause, that "we always think, feel, and want much more than we are able to express" (ibid). ${ }^{4}$ In other words, the limits of language are not absolute. Both in terms of social convention and individual human interaction, people can live at the boundaries of the sayable - and extend them. Thus, Adler posits that the range of human experience continuously calls us, his readers, to get better at expressing ourselves in language and understanding our shared communications.

The form and content of "Die Grenzen des Sagbaren" is useful for a reading of Eine Reise because it sheds light on hopeful aspects of the novel. It is generally acknowledged that Adler's writing can be seen as "Zeugenschaft," or testimony (Vogel-Klein 2011) with a "Poetik des Gedenkens," or poetics of commemoration (Krämer 2012). Adler pushes the boundaries of the sayable and affirms the attempt to remember, represent, and commemorate human experience, if imperfectly. Elsewhere, Adler emphasizes the importance of trying to understand, pointedly stating that those who have not experienced the trauma of the Holocaust should be quiet and listen (H. G. Adler 2017, p. 172). Adler urges the reader to persist in good faith in order to understand and ultimately contribute to the "Something" (H. G. Adler 2017, p. 172) that should follow in the wake of terrible tragedy.

It is a regrettable irony that Adler's work, with its earnest, open, and honest attempts to "build a bridge" to the reader, is not more well known. Eine Reise was written in 1950-51 and, after a long quest to find a publishing house, was published in 1962 (J. Adler 2016, p. 33). It tells the story of the Lustig family's experiences with deportation to the camps and then that of the lone survivor of the family, Paul, who experiences liberation. While Eine Reise was certainly read and reviewed favorably by some literary luminaries at the time of its publication (see, e.g., Eckert and Unger 1975), it did not receive canonical status in contrast to other well-known Holocaust literature. Adler's other novels, two of which remain unpublished in archives, did not fare better, although the recent translation of the Shoah trilogy into English has led to increased interest in these works. In speculating as to why Adler's fiction has not been included in more widespread discussions on this topic, Finch and Wolff (2014) refer to Adler's "literary untimeliness" (p. 3). Krämer (2012) explains an aspect of this untimeliness as the differences in style and content that distinguish Adler from the early phase of so-called witness literature with its straightforward, documentary style (p. 6) and the later "postfactual Shoah-literature" with which Adler shares stylistic similarities but diverges from the non-fictionality of childhood memoirs (p. 86). Filkins (2008) refers to the "mundane quirks of publishing," Peter Suhrkamp's "categorical ban," as well as Adler's "deep disagreement" with Adorno regarding the possibility of art after Auschwitz (p. xi).

\section{Adler vs. Adorno}

Post-Holocaust theory can be divided into two broadly defined camps: those who acknowledge the possibility of human values or ideals and those who collapse human values and ideals into the abuses made of them to posit a theory of totalizing evil. J. Adler

3 Das Schaun ist vor und über aller Sprache, und Sprechen ist, vonseiten des Schauens betrachtet, selbst nur ein bestimmtes Vereinschaun der Zeichen und des Bezeichneten.

4 Wir denken, fühlen, wollen immer weit mehr, als wir auszusprechen vermögen. 
(2000) sheds light on this distinction with his discussion of the differences between Adler and Adorno vis à vis the representation of the Holocaust and the possibility of art after Auschwitz. Since "for many thinkers, even his opponents, [Adorno's] argument defines the parameters of modernity and the debate about how the 'Final Solution' can be represented," Adler's works, based on a contrary stance, pass "unnoticed in English and American" scholarship on the Holocaust (p. 72). As J. Adler (2000) tells us, Adler and Adorno exchanged letters for at least a decade after the war and, though it never came to an open break and Adorno helped Adler secure much-needed funding for the publication of Theresienstadt 1941-1945, this was a fundamental point of disagreement between them ( $\mathrm{p}$. 92). While Adorno holds the position that the Western intellectual tradition led irrevocably to the Holocaust, and that leads to his famous pronouncement that writing poetry after Auschwitz is barbarism, Adler seeks to recuperate and revitalize some aspects of that tradition and does this through a meaningful use of language.

Jeremy Adler rejects the "gospel of aporetics, of non-identity" (Rose 1993, p. 63) present in the Adornoesque tradition in Holocaust scholarship (J. Adler 2000, p. 72). He states that Adorno's "fashionable negation of humanity ... leaves a moral vacuum that has no place for humanity" (J. Adler 2000, p. 95). Accordingly, the abdication of judgment that must follow the dissolution of all stable values leads to a "profound contradiction":

Did we not possess precisely these categories [of value], we would have no means of judging that a crime had taken place, let alone a crime of such enormity. The fact that the crime defies our normal system of belief, our senses, our empathy, our judgement and all our categories, does not invalidate that system as such. On the contrary, the existence of the abnormal can only be recognised by categories like these, and anyone who claims that a monstrous event occurred implicitly relies on them, however inadequate they may be. (J. Adler 2000, p. 73)

As he formulates elsewhere, “Enlightenment values didn't fail us during the Third Reich but rather people did" (J. Adler 1998, p. 216). ${ }^{5}$ Scholars who embrace the position that the overwhelming evil of the Holocaust erases any possibility for good, or that Western culture is inherently barbaric and led irrevocably to the Holocaust, fall into a "fallacy of negativism" (J. Adler 2000, p. 73). While Adler certainly shared intellectual ground with Adorno-they "shared a critical view on the character of modern culture and a Krausian detestation of the media in sustaining the status quo" (J. Adler 1996, p. 19)—Adler asserts the possibility of good, that is, human decency, in the face of evil. As H. G. Adler (1958) states, "language has been entrusted to human beings for their use, and their decisions are just as free here as in the realm of action, as good or evil deeds" (H. G. Adler 1958, p. 257). ${ }^{6}$

Given Adler's affirmation of certain aspects of tradition and the ability of language to serve human relationships, it seems unlikely that Adler's work is "grounded in a sense of a historical and cultural slide towards a postmodernity" that points to a "total unraveling of centuries of progress in human affairs" (Gwyer 2014, p. 69). J. Adler's (2000) contention, namely that Adler's worldview holds "that a system of beliefs, ethical values and the basic political concepts of human rights and democracy do make sense" (p. 73), seems much more likely. As H. G. Adler (1964) reminds us at the beginning of "Bestand und Verwandlung," he is not interested in theoretical approaches that are separate and distinct from life itself. Thus, he prefers the term "Lebensanschauung," or approach to life (p. 251), to theory. The "task of theory," he asserts, "is to forge the path back into the practical; the approach to life becomes again life itself" (ibid). ${ }^{7}$ In contrast to how some post-Holocaust theory might read any in-between spaces, such as those between words and utterances, to Adler, these spaces are not lacunae but calls to make connections and to act.

\footnotetext{
5 Nicht die 'Werte' der Aufklärung scheiterten im Dritten Reich, sondern die Menschen.

6 Nun ist aber einmal die Sprache dem Menschen zum Gebrauch überantwortet; die Entscheidungen stehen ihm hier so frei wie im Bereich des Handelns als gute oder böse Taten.

7 Ihre Aufgabe ist es ... , den Weg zurück in das Praktische anzubahnen; die Lebensanschauung wird wieder zum Leben selbst.
} 
Adler does not, however, deliver neatly communicated messages. As Wolff (2019) remarks, the "modernist quality" of his literary work "resists easy consumption and interpretation" (14). J. Adler (2000) notes:

[Adler's novels] are grounded in the modernist tradition of Kafka, Joyce, and Broch. They defamiliarise events by avoiding references to any national stereotypes, whether Jewish or German, by employing a host of techniques-documentation, montage, stream-of-consciousness, irony, lyricism-in order to mediate the unimaginable. The disaster experienced by others thereby becomes ontologically problematic for the reader. p. 83)

Early reviews of Eine Reise tended to avoid mentioning its polyphonic style (Vogel-Klein 2010, p. 93; Eckert and Unger 1975). However, most recent scholars centrally locate its style in their analysis and tie it to the complexity of the content and the problem of representation (e.g., Filkins 2008, p. xiii; Vogel-Klein 2012, p. 399; Menzel 2016, pp. 194-95; p. 289; Krämer 2012, p. 90). Both Vogel-Klein (2012) and Menzel (2016) show how the clash of discourses creates an "unheimlich," or uncanny, effect to produce dread.

Yet the result of this polyphony is not one of inaccessibility: Adler's texts open up to the patient reader. There is a narrative voice larger than the chaos, outside the chaos, containing the chaos, even if it seems to go mute at times. Vogel-Klein (2012) promises that close reading will reveal an organizing narrator behind the polyphonic style (pp. 399-400). Moreover, this technique lays bare the dishonest and hypocritical system of National Socialism, culminating in a denunciation of the perpetrators and their helpers (Vogel-Klein 2012, p. 407). Thus, while "fragmentation," according to Filkins (2016), "is at the heart of Adler's method" in the published novels, Adler's ability to "unfold and arrange the 'split pieces' of his life and eventually bring them back together" in his writing (p. 59) is also a key to his style. Indeed, as Filkins continues, noting Adler's doctoral dissertation in musicology: "The Journey is more like a piece of polyphonic music whose chords and instruments interweave with and echo one another in rendering the entire composition" (p. 59). I, too, read a counterpoint to chaos and dissolution in Adler's ability to compose with language.

Adler's attempt, first, to represent the horror of the Holocaust so that, second, the reader can, in some small way, begin to comprehend the experience, is vital to an analysis of Eine Reise. While his fiction is commemorative in this way, Adler's attempts at the "restoration of memory" (Filkins 2008, p. xxi) exist in a "combination of grief and optimism" that lends Adler's writing "a special tension" (J. Adler 2017, p. 811). In what follows, I explore the ways Adler creates optimism in Eine Reise, reinvesting language-the ability for words to come together to express meaning-with trust after it has been thoroughly taken apart. The fragmentation evident in the novel also urges readers to make connections and associations that lead to reliable and stable meaning, and the similarity to his thoughts about language in "Die Grenzen des Sagbaren" will clarify moments of insight in the novel. Our current theoretical moment has become so obsessed with impossibility and inexpressibility that it tends to overlay post-Holocaust fiction with a "fallacy of negativism" (J. Adler 2000, p. 73) and encode it with "necrotic memory" (Finch 2016, p. 258). Vogel-Klein (2012) also rejects such obsessions as inappropriate when it comes to Adler specifically and the literature of the Holocaust generally (p. 397). By siding so completely with Adornoesque pessimism, many current theorists plunge an abstract humanity into alwaysalready badness, instead of acknowledging, as Adler did, that there is good and evil in the world, in people, and reflected in texts. The difficult task is to distinguish between good and evil in real time and space. When Adler calls upon his reader to participate in "Something" rather than "Nothing," this is what he means.

\section{Eine Reise}

My thesis has elements in common with work done by other scholars. For example, Finch (2016) reads a "Kafkaesque hope" in Panorama and The Wall that she connects to "an ethical mode of attention, one that involves listening carefully and responding to their 
moral challenges" (p. 251). She notes the Holocaust testimony of Adler's novels and "the ability to transcend its particular circumstances" as well as the "act of commemoration" that opens them up "to a hopeful future" (p. 258). Finch connects these aspects of Adler's work specifically to his admiration for Kafka and the tradition of Prague-German literature regarding language. Menzel (2016) analyzes moments of "nothingness" and "something" in Adler's "narratives of survival" but stops short of connecting these moments to a future beyond the "meaning of survival" for the individual (p. 130). Krämer (2012) also analyzes many moments of hope in Adler's Theresienstadt 1941-1945 (H. G. Adler 1960) and the Shoah trilogy, but limits his analysis to the possibility of reconstructing an identity through the process of memory work. In my view, Adler's commemorative fiction and scholarly writing transcend a focus on his personal identity as a survivor and look to bridge the gap between saying and understanding with the reader to foster understanding and moral development for "future world citizens" (Wolff 2016, p. 292). With Filkins, I would say that commemoration, "when conducted on the highest plane," does not "succeed through bombast or blunt instruction, but rather through careful modelling, subtle delineation, and understated, shared moments of revelation" (Filkins 2019, p. 59). In what follows, I investigate how Adler accomplishes this feat in Eine Reise.

It is worth pausing here to note, as several other scholars have, that, in Adler's view, the causes of the Holocaust had their roots in the urgent problems of modernity that preceded and outlasted National Socialism (e.g., Finch 2016, pp. 251, 254; Krämer 2012, p. 61; H. G. Adler 2017, pp. 560-66). Indeed, Adler recognizes a general crisis in Western culture and captures it in the term "mechanical materialism" (H. G. Adler 2017, p. 561). As J. Adler (2016) explains, this term signifies "an absolutely materialist view of life" which entails "the philosophical denial of all organic complexity" (p. 44). As H. G. Adler (2017) himself makes clear:

The consequence of turning every human being into a number denoting an "item" is obvious if life becomes a thing; this has become an almost uncontested practice in the administration of modern states. Instead of serving to create order in life, administration imperiously becomes an end in itself, and life, as an administrative matter, is recognized only for administration's sake. Once overmechanization is taken seriously and all moral inhibitions fall away, National Socialist treatment of human beings is only a small step away. (p. 562)

Adler's broader view of the causes of the Holocaust also explains in part why he avoided referring to any particular nation or people in Eine Reise. It also explains his polyphonic, modernist style and use of associational strategies to achieve an "organic complexity."

In order to illustrate Adler's narrative strategy and poetic attention to language, Filkins (2008) cites the repetition of "Abfall," or rubbish, in Eine Reise and notes the problem this caused for him as the translator. "Abfall" can mean rubbish but also denotes humanity's original fall from grace (p. xiv), demonstrating the multivalent meaning in the specific words Adler chooses. Vogel-Klein (2008) similarly analyzes Adler's use of the word "Reise," or journey. Rather than focusing on a specific metaphor, however, I will examine other associational moments in Eine Reise, contrasting decay and disintegration with moments of hope and the possibility of real connection and communication.

Adler uses different metaphors and his polyphonic, associational strategy to depict how things fall apart as ordinary, everyday reality is transformed into a nightmare. Characters are stripped of previously reliable means of orientation and subjected to dehumanizing processes. The disintegration of all fundamental relationships in the camps, what Krämer (2012) calls the "Zersetzungstendenzen des Konzentrationslagers" (p. 196), already begins when the family at the center of the novel, the Lustigs, whose name is an ironic commentary on their situation, are ordered to leave their apartment. "Thou shalt not dwell among us!" (H. G. Adler 2008, p. 8), they are told.

Subsequently, the German verb "to dwell" (wohnen) and noun "apartment" (Wohnung) create other (biblical) associations, such as the dignity of dwelling in one's own person. Once their "dwelling," both as a verb and a noun, is forbidden, a process of 
disintegration begins as people, the "souls of these buildings" (p. 231), are separated from their apartments, which makes the world "uninhabitable" (unwohnlich, p. 281). The now empty apartments are described as destroyed, even before the bombs drop, because their occupants, their living entities, have been removed: "There were no more apartments that lasted long enough to become ruins, there were only empty brood houses, ransacked shells, or illegitimate goods worthless even to looters. But this happened much later and was never seen by the afflicted, who long before had been told, 'Thou shalt not dwell among us!'" (p. 8). After its people have been removed, "the apartment is dead ... . There sleep, night, dust, and cold exist. There nothing exists" (p. 17). The apartment's emptiness or nothingness stands for this breakdown of ordinary reality and the metaphysical void that opened up with the cessation of a humane rule of law. These things (i.e., sleep, night, dust, cold) do exist but they no longer have the same meaning. The connections between them are lost as well, as is their ability to function as points of orientation in ordinary reality: There nothing exists. The passage continues: "Not a single memory is there. .. Now the furnace can remain silent. The ashes will not be taken out" (p. 17). Dust and ashes are a leitmotif in the novel, turning up in what seems like every nook and cranny, standing for themselves but also creating a sense of dread that permeates everything, anticipating the reality of another furnace, the crematorium that is introduced much later.

Fragmentation is at the forefront of Adler's strategy and he uses the image of bricks and mortar as one way to depict the process of disintegration and loss of cohesion. In addition to being used for actual structures (e.g., walls and houses), Adler's bricks are multivalent building blocks, standing for people, meaning, and life itself. In the following, Adler describes a brick wall, conjuring up images of human beings clinging to ordinary reality as it slips away: "[E]ven the stones that are still held together await the hands that will rip them apart later. The mortar between the individual bricks will tire of fending off the picks and will begin to crumble into dust. But that is not yet the case, that will take time, that will be put off until later" (p. 14). "Later" comes and the connective material yields as the wall is demolished (p. 43). The "women stand below with half-frozen fingers, cleaning the last of the mortar off of the bricks with iron scrapers" (44) and are thus forced to participate in the dissolution process. A subsequent passage uses words that foreshadow human fates, again connecting human beings with their dwellings. I have re-translated key verbs to highlight this connection: "As soon as a building [receives the death sentence], no concessions can be made and it must be quietly [carried off], rather than stripped of all its components" (p. 44; H. G. Adler [1962] 1999, p. 48). Adler uses the terms "death sentence" and "carried off," connecting the destruction of the houses explicitly with the people who lived in them.

After their apartments and their possessions, the "forbidden ones" are separated from their names: "[E]verything must be relinquished. ... IDs that vouch for the names on them are separated from the nameless phantoms, because the permission for them to remain together must be denied" (p. 13). People without names are people without rights (p. 23) and then become numbers (p. 29). When they arrive at the camp, the prisoners do not immediately process their new reality. The gap between their fate and their understanding of it is signaled in the following passage by the shift from being people with numbers to just existing as numbers and recalls the above passage from Theresienstadt 1941-1945:

Then came the separation. Numbers were called out and then names as well, for not everyone was used to having a number, and some actually thought that they would not wear numbers forever and would forget them soon enough like so much else, hardly having put any effort into remembering them. But now the numbers were separated and sent here and there. (p. 40)

In order to create powerful dissonance in the novel, the disintegration or separation of things that used to belong together is contrasted with a re-ordering of things in inhuman ways that results in the "grinding down of character" (H. G. Adler 2017, p. 209). Commands are carried out, camps are built, human beings are coerced, starved, beaten, and murdered. As noted above, Adler's modernist style includes juxtaposing conflicting discourses to 
heighten the sense of irony and dread as well as to highlight the enormity of the crimes (e.g., Vogel-Klein 2012). In Eine Reise, Adler combines things that do not belong together in any humane order to heighten the sense of Theresienstadt as a "coerced community" (H. G. Adler 2017) or an "inhuman network that consumes us all" (H. G. Adler 2008, p. 58). The original German phrase that became "inhuman network" in Filkins' translation is "unmenschliches Flechtwerk" (H. G. Adler [1962] 1999, p. 63). In this context, I prefer the German phrase because it more strongly connotes an active process of putting, that is, weaving, together. Adler uses another image to convey the results of this force, which has destroyed the integrity of human beings in true degradation that leads to putrefaction. Things dissolve into "Brei," or some kind of paste. While the original text repeats the word Brei, with intensifying modifiers, Brei is translated as "complete muck" (p. 33), "brown smelly paste" (p. 42), "sticky paste" (p. 43), and a "disgusting gruel" (p. 84). Interestingly, Brei is also something that can be eaten and thus is translated twice as "gruel" when eaten by Ambrosius, a resident of the town the prisoners are marched through with regular frequency (p. 92) and once by Dr. Lustig (p. 127). This implies that everyone was consuming as well as being consumed by the horror.

The "brown smelly paste" (p. 42) is a potent metaphor-the results of a grinding machinery that is unconcerned with the integrity of human beings qua human beings-but it is not mentioned again once the crematorium is introduced (p. 133). The passages leading up to the first mention of the crematorium make clear the ultimate result of this process: the transformation of human beings into disposable things. Another "unmenschliches Flechtwerk" brings together the paving of the camp roads with human remains. (The paving of roads in Theresienstadt actually occurred during the ghetto's beautification process in preparation for the visit of the International Red Cross in June 1944; see H. G. Adler 2017, pp. 135-49.) The paved road is described as a boon-“[p]avement means dryness, peace, security"-while the process of pouring the tar evokes images of death and consumption: "a dark syrup, blood gone black, honey of the dead and their inextinguishable memorial, poured out from large drums and pressed into an iced cake" (p. 130).

Passages follow describing how the paving of the roads is completed: "Fine macadam is spread upon the tar with flat shovels, and then soft wide squeegees evenly distribute it. Once more orderliness has won the day. Now the steamroller effortlessly completes the task by reducing the stone and tar to a uniform smoothness... The macadam is tamped down, embedding itself completely in the tar" (p. 130). Evident are the over-concern with even distribution, orderliness, and uniformity and the almost human concern with the macadam coming to rest in the tar. This paved road also leads to happier horses as they pull the wagons of the dead (I have included original German words for emphasis): "The horses pull more vigorously and Ruhenthal's load of [abgefallene] human freight sways across the sand-based macadam and tar. The barrier falls, the farewell is completed. Merrily [lustig] lurching ahead with sprightly speed, the funeral wagon rumbles along" (p. 131; H. G. Adler [1962] 1999, p. 142). After the jarring contrast between the caring for the tar, surely the result of the beautification project, the indifferent joy of the horses, along with the repetition of "abfallen," which sounds the note of rubbish and apostasy again, and finally using the adverb "lustig" to describe the funeral wagon's "rumbling" after Dr. Lustig has perished of starvation, the transformation of human beings into things culminates in the final passage:

The crematorium situated on clay soil in the middle of the meadow works well and reliably, and there hasn't been the slightest complaint about it since it was opened. It works fast and is free of dust. The ashes are filtered and crushed and converted from morsels to crumbs, which are then spread upon tar and quietly [friedlich] pressed into it. (p. 133; H. G. Adler [1962] 1999, p. 145)

The murdered ones have thus become part of the road. The offhand mention of the efficient crematorium as part of the landscape and the quiet, or peaceful in the original German, merging of human remains with the tar as a final resting place, makes this passage perhaps 
even more unsettling than other passages in the novel which depict the crematoria as hygienic wonders appropriate for the modern, civilized household (pp. 193-94).

Scholars emphasize Adler's effectiveness in depicting, with multiple tone and style changes, what Rousset (1946) termed l'univers concentrationnaire, or the universe of the camps (e.g., Wolff 2019, p. 7; J. Adler 2016, p. 27). Indeed, Adler's polyphonic evocation of horrific events is difficult to read and understand, both in terms of content and style. For this reason, some scholars have interpreted an abyss of nothingness as the metaphysics of Adler's work and use the following oft-cited passage from Eine Reise, which takes place at the end of the war, to support their claims:

[W] hat the chopped-off hands point to doesn't make sense. They don't point toward anything and don't connect to any idea but are pointless direction with no end. Thus everything is senseless. The eye focuses and then discovers names next to the hands. They once named roads. Yet now there are no roads. The names mean nothing, they are faded, the color having drained from the names, separated from the hands, which are nothing more than dust-covered stumps. And no matter how much the gaze wishes to join together the hands and the names, it still cannot figure out how they belong to each other; they are so badly injured that they no longer mean anything. The names are mixed up and cannot find their owners. (p. 199)

The "dust-covered stumps" recall the brutal separation of human beings from their homes, their names, and their lives. J. Adler (2000) remarks on how this passage depicts a "universal catastrophe" (p. 82) and a "self-cancelling emblem which represents the collapse of all meaning" (p. 83). Some scholars cite this passage (and Jeremy Adler's analysis of it) as confirmation of the absolute epistemological instability in Adler's work.

A totalizing interpretation, however, overlooks other associations one can read in this passage. It echoes, for example, the conclusion of Adler's essay on "Die Grenzen des Sagbaren." As he notes, language means the ability to see the connection between the sign and the signified, and that has been temporarily disrupted in this passage from Eine Reise. However, we still "always think, feel, want much more than we can express" (H. G. Adler 1965, p. 103). I read in this passage, as it continues, Adler's attempt, via other kinds of associations, to contrast a mechanical, one-to-one correlation between ideas and objects with "organic complexity and psychological individualism" (J. Adler 2016, p. 44).

At this point, I should note that Adler does concede the near impossibility of coming to terms with the dissolution of former structures of meaning in the camps. In Theresienstadt, people "were violated by deceptions. These deceptions could pass by as dreams. However, just when one wanted to see them as a dream, they became reality. Just when one wanted to take them for reality, one realized once again that they were deceptions" (H. G. Adler 2017, p. 587). However, Adler does not concede all possibility of meaning-making and ends this passage in Theresienstadt 1941-1945 with the following: "Thus the camp became a unique test. Existence and nonexistence had gotten mixed up. The last eschatological questions obtruded themselves, as they do wherever people find themselves faced with the outermost limits, with the apeiron" (ibid).

Thus, while I would agree with Gwyer (2019) to a certain extent that, in Adler's novels, "their subject matter becomes the breakdown of their own structures" (p. 71), Gwyer's totalizing interpretation, namely that all points of reference are subverted, that is, "any notion of causation, coherent space, and independently cognizant subjectivity" (p. 74), ignores the moments of resonant affirmation in Adler's work. Scholars who approach Adler with an absolute epistemological and existential pessimism do so via postmodern theoretical positions, which have much in common with Adorno's cultural pessimism and are of dubious applicability to Adler's work. According to Adler, when people are confronted with apeiron, or a boundaryless, overwhelming threat, these "last eschatological questions" force their way through to human consciousness. How shall people answer these questions? How can one take the first step in a meaningful direction? After suffering such loss, how can a human being even begin the process of making meaning? Or with 
H. G. Adler (2017), we ask again: "What must happen so that this end, which was Nothing, can still be followed by a beginning that would be Something?" (p. 172).

Immediately following the passage cited above from Eine Reise, Adler's narrator continues describing the physical, ontological, and epistemological chaos, in which the lone survivor of the Lustig family, Paul, attempts to make sense of things. The possibility of something other than absolute destruction emerges in the space between names and the things they no longer denote:

The names are mixed up and cannot find their owners. Yet there are no owners, there are just Anybodys, who are not names and not hands, but rather figures that belong to no one and which creep between the hands and the names, looking for a direction in which to head, although the eye sees no direction to recommend to them. They turn this way and that, each step changing the direction, they grow tired and appear to rest, but only for a short while, an irrepressible driving pushing them on. Yet there is no road they can take, since none exists. Each Anybody appears to be in the same situation. Perhaps each one knows that he has never been here, but rather has been transformed here. Back then it was someplace else altogether, but he cannot recall, he does not remember the name or the direction. This one with an idea is unsure of what is Nothing or what is Something, then he chooses Something. (pp. 199-200)

In this passage, Adler effectively depicts the disorientation as well as the "irrepressible driving" force that counters nothingness.

Choosing "Something" over "Nothing" is a pivotal moment. The passage continues with the beginning of a return to personhood:

He feels overwhelmed by a past he does not know, yet which he can sense, Something having won out after all. This grants great courage and strength to the body, allowing him to decide to act. As soon as he exists, then he can ask questions. He stops another Anybody and tries to gain his attention. That doesn't work. Anybody doesn't stop and stumbles on uncertainly, not knowing he himself is a Nobody and not even an Anybody. Yet he tries again to help this Nobody recognize Something, and indeed, he's there, he gives a start; is he in fact now an Anybody? Yet he does not know anything, but rather mumbles dark sounds from an unknown tongue, it all having been a mistake. Better to try something else. The Question asks the Question whether Anybody knows which way to go? No, Anybody doesn't know, he knows no one in these parts. There are no roads here, they are elsewhere. But there must be roads, says the answering voice. The word road means something. Because of it this conversation makes sense and therefore has meaning. (p. 200)

With this first step into meaning, the "he" of this passage gets closer and closer in consciousness to Paul who is the definitive narrative consciousness at the end of the novel (Filkins 2016, p. 54; Krämer 2012, p. 182). Once "the word road means something," the narrator rejects nihilism and takes a step towards reconnecting words, objects, and people in real time and space. He decides for a concrete destination, follows the direction indicated by a hand, and walks the eight kilometers to Unkenburg, or "town of toads" (p. 204), a fictional stand-in for Halberstadt (J. Adler 2008, p. 291).

The abstract and metaphorical language in the above passages foreshadows Paul's actions and experiences in Unkenburg, and the putting back together of that which had been taken apart. With his decision to follow a road, Paul steps from "Nothing," or apeiron, and begins his search for an "Anybody," that is, someone capable of understanding the "Something" that must follow. Once in Unkenburg, Paul tries multiple times to speak with people and describe his recent experiences. He fails, as they fail to understand him. As Finch (2015) notes, however, this does not amount to "any linguistic aporia of communication, nor [to] insisting on a sacred gap between experience and language that can never be resolved" (p. 438). This stage of Paul's "journey" (p. 270), that is, 
re-establishing actual communication and finding a difficult, but possible, path into the future, consists of two parts. At first, Paul must figure out how to reassert his human will and creativity. He must travel the road back to personhood, or "erneute Ich-Werdung" (Krämer 2012, p. 165). Second, Paul must restore the possibility of connection to another human being who is willing and able to understand. Significantly, Adler's prose style shifts during this final section of the novel and gradually becomes clearer and less fractured, thus mirroring Paul's return to some sense of self and to the possibility of communication that can be understood (Filkins 2016, p. 53). What follows, I believe, is some of the most moving prose in German-language literature.

Paul's attempts to reclaim his personhood have varying degrees of success. The unsuccessful moments, however, are equally important. He knocks on a stranger's apartment door and asks to be let in, just so he can see what an apartment looks like but realizes, after a conversation with the woman who lives there, that this will not restore his lost dwelling (p. 239). He recognizes that his situation calls for compassion and helpfulness but refuses to register with the "Office for Former Prisoners" because he "wants to have an official designation for himself in the present, not an honor granted to the past" (p. 249), and so he moves on. However, later he returns to police headquarters to request identity papers, that is, the official restoration of the connection between his name and his person, which he is granted. His signature is an assertion "that Paul can exist" (p. 276). His refusal to be treated indifferently by "Captain Dudley," who is more interested in collecting "medals of the defeated" (p. 250) than helping, leads to a significant realization. Paul leaves, saying: "Excuse me, I made a mistake! I was looking for a human being. I knocked on the wrong door" (p. 252), indicating that he now knows what constitutes an "Anybody."

Immediately following this encounter, Paul meets an "Anybody" in Herr Brantel, who tells him as an act of kindness that the army barracks are now empty. Subsequently, Paul claims a room there for himself (p. 254), sleeps a death-like sleep in which he must descend into the depths of a void, another important step in reclaiming his personhood, and from which he re-emerges with the will to live (pp. 255-58). He catches a glimpse of himself in the mirror for the first time in a long while and cannot "prevent himself from sobbing constantly and crying helplessly and watching his own tears fall" (p. 260). This acceptance of the transformed man in the mirror is profound (see J. Adler 2016, p. 40). Paul then asserts his right to dwell in the room he has chosen and hangs a piece of paper on the door with the statement: "Here lives Paul Lustig, please knock!" (p. 267). After the traumatic dispossession that began the novel, claiming a dwelling and asserting its boundaries is affirming of both self and the possibility of human integrity.

As indicated in "Die Grenzen des Sagbaren," an important step in the history of human understanding of language occurred when it became clear that words are both entities unto themselves as well as radiating units of meaning. Similarly, human integrity requires the boundaries of personhood as well as the ability to connect to others. Paul realizes that finding his way back to a singular personhood is not the ultimate or only goal of his continued existence and to treat it as such would diminish it (p. 278), perhaps resulting in solipsism. Paul's next challenge is to communicate his experiences to someone who is willing and able to understand. After Paul encounters Herr Brantel again, he becomes a welcomed guest: "Wine is served that has been waiting for him to taste. He is asked to talk about what happened, so Paul talks about the journey. At last, he can say what it was like. He quietly talks about it without emotion... People listen and are quiet" (p. 270). This moment reminds the reader of the passage from Theresienstadt 1941-1945 where Adler exhorts people who have not experienced the Holocaust to be quiet and listen (2017, p. 172). After meaningful exchanges with Herr Brantel and his family, Paul is able to say: "The journey calls, each of us is called to take it. I thank you for all the kindness you have shown me. I leave your house wholly recovered" (p. 279).

Scholars of Holocaust literature who focus exclusively on the obligation to remember might characterize the cautiously optimistic and hopeful ending as out-of-step with the rest of the novel. These last moments of hope and optimism, however, are actually not singular. 
Indeed, they begin in the "Vorzeichen," a preface of sorts, translated by Filkins (2008) as "Augury" (p. 3). The multivalence of the word Vorzeichen is difficult to render in English because, in addition to augury, it can also indicate the sign that makes a number positive or negative, as well as the key signature which sets the tone for a musical composition. Given Adler's attention to the multivalent meanings of words, all these meanings are vital to an interpretation of Eine Reise (see also Krämer 2012, p. 171).

The Vorzeichen is thus not simply a predictor of future events but also is the key that sets the tone of the novel, grounding the narrative in moments that transcend the penetratingly ironic and "vitriolic" passages (Filkins 2008, p. xxi) that make up so much of the novel's narrative. Indeed, the language and tone of the Vorzeichen are distinct from most of the novel, with the exception of occasional passages (e.g., see J. Adler 2016, pp. 55-56) and the novel's end. Unlike Creet (2016), I do not think it is possible to read the Vorzeichen as anything other than hopeful, as it acknowledges and points beyond the horror and tragedy of events towards transcendence. One recalls Adler's advice to Franz Wurm when Wurm confessed that he could not bear to read Theresienstadt 1941-1945 in any systematic way. In his reply, Adler urged him to read it mainly because the path to freedom lies in looking the truth in the eye. Avoidance of evil allows it to continue to exert power over oneself (Atze 1998, pp. 140-41).

For Krämer, the Vorzeichen situates the novel's "tale" in an existential context that cannot be exhausted by the Holocaust. That existential context, in his interpretation, is "the journey" back to self-hood, a self that can become a self once again through the process of remembering (p. 171). While Krämer limits this self to a question of Adler's personal identity, in my reading, Adler is pointing us to some more general truths about the human condition. These truths are outlined-in association-in the Vorzeichen and encompass what it means to be a singular identity as well as a human being. It is important to note that Adler also affirms something other than the abstract conceptualization of apeiron or cult of commemoration. Indeed, his agreement with Hermann Broch about the modern "disintegration of values" (Adler and Broch 1999, p. 146) suggests there is a tradition of value that requires our engagement rather than wholesale rejection. As H. G. Adler (2017) notes multiple times in Theresienstadt 1941-1945, the murderous regime is beyond justification but not everyone who perished is worthy of emulation (e.g., pp. 205-24). In the closing pages of the novel, Herr Brantel accompanies Paul down a dark staircase out into the street, holding a candle and shielding its flame (p. 279), demonstrating that there is something other than individual identity or abstract commemoration that we need to protect. Thus, the end of the novel evokes its beginning to address questions of value.

A definition of value in this case eludes an entry of the type dictionaries contain. In Eine Reise, Adler composes it with an orchestra of detail and association because, as the narrator states, "to try to depict this rather than describe it is the best response" (p. 5). The narrative voice of the Vorzeichen is confidently compassionate and comforting, though also abstract and difficult to comprehend. The narrator reminds us that, despite immeasurable suffering, suffering is not all there is-it belongs to a world of fleeting appearances. Adler associates the fleeting nature of a singular life with the "metaphor of the journey" and contrasts this with the permanence of what it means to be human, that is, an "entity capable of remembering itself" (p. 4). This commemorative ability-one that echoes Adler's point in "Die Grenzen des Sagbaren"-allows us to arrive at some measure of peace as we remember what it is that makes us human despite the suffering:

$[\mathrm{P}]$ eace is let go and is gone, though not entirely; its reflection is and remains discernible for anyone who remains aware, amid the fear and horror of each single moment, when all dignity and secrecy are threatened, that an indestructible kernel persists beneath all the terror of this theater of horrors, a center, one which should never be idealized, since its existence is known only to the searching heart. (p. 5)

The "idealized," that is, something which exists only in the realm of ideas, evokes its opposite in H. G. Adler (1964) concept of "Lebensanschauung," or approach to life, mentioned 
above. The "searching heart" can know this "ideal" in the real world. Thus, despite the threats to "dignity and secrecy," the existence of an "indestructible kernel" means that "we are not lost, even when we assert our loss" (p. 5), and "we are not forsaken. We are never forsaken" (p. 6).

The "Something" beyond unspeakable evil is a good that is also not completely expressible in language. The "indestructible kernel" or "center" of human existence is mentioned again at the end of the novel in a brief conversation between Paul and Herr Brantel (see also Krämer 2012, p. 169). Brantel notes:

One must have a center, an unshakable quiet space that one clings to vigorously, even when one is in the middle of the journey, the unavoidable journey ... an unmuddied sensibility free of rubbish, no left, no right, only the center, a constancy that does not change for the better or for the worse. I don't mean it strictly in a spatial sense. I mean it instead as a circuit, one that travels from hand to hand, from heart to heart and really exists. (p. 281)

In contrast to the hands that lay disembodied and dismembered on the ground, here the human hand creates connections that "really exist" between people. This "circuit" recalls the "bridge to a you" mentioned in "Die Grenzen des Sagbaren" (H. G. Adler 1965, p. 98) and the responsibility each one of us has for improving our ability to use language meaningfully and thus communicate with others. After their conversation has ended and Herr Brantel has left, Paul continues to feel Brantel's hand on his shoulder (p. 282).

At one point, the narrator in Eine Reise refers to a "fairy tale of nothing, the fairy tale devoid of magic, betrayal that cannot betray, steps that lead nowhere and without reason and without sense, where no one gets on and no one gets off" (p. 198), which can be read as a rejection of Adorno's brand of pessimism (J. Adler 2000, p. 96). After liberation, Paul refers to a people "that has a propensity for the negative" as well as the world that "degenerated into lovelessness and then into madness" and "was destroyed and made uninhabitable" (p. 280), also clearly rejecting absolute pessimism. Despite the existence of despair and uncertainty in Adler's work, they do not represent the sum total of human experience for the simple fact that, if there is only evil, then there is no evil. Without standards of reference by which we can define evil, and that would presumably be good, then evil does not exist.

\section{Closing Thoughts}

One notes, in some Adler scholarship, a general discomfort with the word "truth," a discomfort that derives from postmodern theoretical sources. Others, such as Filkins and Jeremy Adler, who have surely spent countless hours immersed in Adler's work, are more comfortable with using the word and the concept. For example, Filkins (2016) calls Adler's "private truth" the glue that holds the "truth" depicted in the trilogy together (p. 65), though it seems to be chaos. Filkins (2016) notes that Adler the author remains "present in [The Journey's] many observations about truth and reality, and what survives and what does not" (p. 56). J. Adler (1998) explains:

The concept of truth we encounter in Adler's work combines this subjective experience of the witness with the appeal to an objective authority: God as lawgiver. However, since Adler wants to bear witness in scientific form, he uses at the same time the theoretical concept of truth from classical antiquity. Thus, "truth" for him is determined scientifically, existentially, and religiously. (p. 212) ${ }^{8}$

I would add here that, for Adler, the truth is not solely a phenomenological quest. He does not just report what he saw or experienced, but rather explores why the evil occurred and how one might move forward, individually and collectively. In so doing, he does not side with pessimism. Instead, Adler affirms certain traditions of value and locates

8 Der Begriff "Wahrheit," den wir bei Adler vorfinden, verbindet diese subjective Erfahrung des Zeugen mit der Anrufung einer objektiven Instanz: Gott als Gesetzgeber. Da aber Adler in wissenschaftlicher Form sein Zeugnis ablegen will, verwendet er gleichzeitig den theoretischen Wahrheitsbegriff der Antike. So ist "Wahrheit" für ihn wissenschaftlich, existentielle und religiös bedingt. 
these questions in the realm of the approachable and the knowable. This opens up a space where we as his readers are left to think and decide what is to be remembered. This is not an abstract or theoretical remembrance but a call to define and adhere to a set of human values, expressible in language, which, if enacted, would go a long way to prevent such a grand-scale tragedy from happening again.

Funding: This research received no external funding.

Conflicts of Interest: The author declares no conflict of interest.

\section{References}

Adler, H. G. 1999. Eine Reise. Vienna: Paul Zsolnay. First published 1962.

Adler, H. G. 1958. Sprachgeist und Sprachverfall. Muttersprache 68: 254-58.

Adler, H. G. 1960. Theresienstadt 1941-1945: Das Antlitz einer Zwangsgemeinschaft, 2nd ed. Tübingen: J.C.B. Mohr.

Adler, H. G. 1964. Bestand und Verwandlung: Versuch einer Lebensanschauung. In Die Erfahrung der Ohnmacht: Beiträge zur Soziologie Unserer Zeit. Frankfurt am Main: Europäische Verlagsanstalt, pp. 251-56.

Adler, H. G. 1965. Die Grenzen des Sagbaren. Muttersprache 75: 97-103.

Adler, H. G. 2008. The Journey. Translated by Peter Filkins. New York: Random House.

Adler, H. G. 2017. Theresienstadt 1941-1945: The Face of a Coerced Community. Translated by Belinda Cooper. New York: Cambridge University Press.

Adler, Jeremy. 1996. The one who got away. H. G. Adler and Theodor Adorno: Two approaches to culture after Auschwitz. Times Literary Supplement 4: 18-19.

Adler, Jeremy. 1998. Der Wahrheit verpflichtet. In H.G. Adler-Der Wahrheit verplichtet: Interviews, Gedichte, Essays. Edited by Jeremy Adler. Gerlingen: Bleicher, pp. 205-34.

Adler, Jeremy. 2000. Good against evil? H.G. Adler, T.W. Adorno and the Representation of the Holocaust. In Social Theory after the Holocaust. Edited by Robert Fine and Charles Turner. Liverpool: Liverpool University Press, pp. 71-100.

Adler, Jeremy. 2008. Afterword: Only Those Who Risk the Journey Find Their Way Home. In The Journey. By H. G. Adler. Translated by Peter Filkins. New York: Random House, pp. 285-92.

Adler, Jeremy. 2016. The World of My Father's Memory Writing: The Gesamtkunstwerk of H. G. Adler. In H.G. Adler: Life, Literature, Legacy. Edited by Julia Creet, Sara R. Horowitz and Amira Bojadjija-Dan. Evanston: Northwestern University Press, pp. $23-46$.

Adler, Jeremy. 2017. Afterword. In Theresienstadt 1941-1945: The Face of a Coerced Community. By H. G. Adler. Translated by Belinda Cooper. New York: Cambridge University Press.

Adler, H. G., and Hermann Broch. 1999. Hermann Broch and H.G. Adler: The Correspondence of Two Writers in Exile. Translated by Ronald Spiers. Comparative Criticism 21: 130-200.

Adorno, Theodor W. 1973. Negative Dialectics. New York: Continuum International.

Adorno, Theodor W. 1977. Prismen: Kulturkritik und Gesellschaft. In Gesammelte Schriften. Edited by Rolf Tiedemann. Frankfurt am Main: Suhrkamp, vol. 10, pp. 11-30.

Atze, Marcel. 1998. Ortlose Botschaft: Der Freundeskreis H.G. Adler, Elias Canetti und Franz Baermann-Steiner im englischen Exil. Marbacher Magazin 84. Marbach am Neckar: Deutsche Schiller-Gesellschaft.

Creet, Julia. 2016. A Dialectic of the Deictic: Pronouns and Persons in H.G. Adler's The Journey. In H.G. Adler: Life, Literature, Legacy. Edited by Julia Creet, Sara R. Horowitz and Amira Bojadjija-Dan. Evanston: Northwestern University Press, pp. $205-27$.

Eckert, Willehad P., and Wilhelm Unger, eds. 1975. H.G. Adler: Buch der Freunde. Cologne: Wienand.

Filkins, Peter. 2008. Introduction. In The Journey. By H. G. Adler. Translated by Peter Filkins. New York: Random House, pp. ix-xxi.

Filkins, Peter. 2016. The Self Positioned, The (De)posited Self, The Soul Released: The Uses of Biography in H. G. Adler's Shoah Trilogy. In H.G. Adler: Life, Literature, Legacy. Edited by Julia Creet, Sara R. Horowitz and Amira Bojadjija-Dan. Evanston: Northwestern University Press, pp. 47-67.

Filkins, Peter. 2019. H.G. Adler: A Life in Many Worlds. New York: Oxford University Press.

Finch, Helen. 2015. Holocaust Translation, Communication and Witness in the Work of H.G. Adler. German Life and Letters 68: 427-43. [CrossRef]

Finch, Helen. 2016. Prague Circles. H.G. Adler's Kafkaesque Hope. In H.G. Adler: Life, Literature, Legacy. Edited by Julia Creet, Sara R. Horowitz and Amira Bojadjija-Dan. Evanston: Northwestern University Press, pp. 251-72.

Finch, Helen, and Lynn L. Wolff. 2014. Eds. and Introduction. In Witnessing, Memory, Poetics: H. G. Adler E W.G. Sebald. Rochester: Camden House, pp. 1-21.

Gwyer, Kirstin. 2014. Encrypting the Past: The German-Jewish Holocaust Novel of the First Generation. Oxford: Oxford University Press.

Gwyer, Kirstin. 2019. H.G. Adler's ‘Grenzgängertum': Trans-Border Travel between Enlightenment Epistemology and Modernist Representation. In A Modernist in Exile: The International Reception of H. G. Adler (1910-1988). Cambridge: Modern Humanities Research Association, pp. 62-77.

Krämer, Thomas. 2012. Die Poetik des Gedenkens: Zu den autobiographischen Romanen H.G. Adlers. Würzburg: Königshausen \& Neumann. 
Menzel, Julia. 2016. Between 'Nothing' and 'Something': Narratives of Survival in H. G. Adler's Scholarly and Literary Analysis of the Shoah. Leo Baeck InstituteYear Book 61: 119-34. [CrossRef]

Rose, Gillian. 1993. Judaism and Modernity. Oxford: Blackwell.

Rousset, David. 1946. L'univers concentrationnaire. Paris: Éditions du Pavois.

Schnelting, Karl B., ed. 1987. H. G. Adler im Gespräch mit Hans Christoph Knebusch. In Jüdische Lebenswege-Nahum Goldmann, Simon Wiesenthal, H.G. Adler. Frankfurt am Main: Fischer, pp. 157-86.

Vogel-Klein, Ruth. 2008. Eine fremde Welt: H.G. Adler, Eine Reise. Germanica 42: 1-13. [CrossRef]

Vogel-Klein, Ruth. 2010. Keine Anklage? Die Deportationsroman Eine Reise (1951/1962) von H.G. Adler. Publikation und Rezeption. In Die ersten Stimmen: Deutschsprachige Texte zur Shoah 1945-1963. Edited by Vogel-Klein. Würzburg: Königshausen \& Neumann, pp. 79-111.

Vogel-Klein, Ruth. 2011. H.G. Adler: Zeugenschaft als Engagement. Monatshefte 103: 185-212. [CrossRef]

Vogel-Klein, Ruth. 2012. Diskurse einer heilen Welt: H.G. Adlers Roman Eine Reise. In Sprachbilder und kulturelle Kontexte: Eine Deutsch-Russische Fachtagung. Edited by Renate Hansen-Kokoruš, Beate Henn-Memmesheimer and Gislinde Seybert. St. Ingbert: Röhrig Universitätsverlag, pp. 397-408.

Wolff, Lynn L. 2016. 'Die Grenzen des Sagbaren': Towards a Political Philology in H.G. Adler's Reflections on Language. In H.G. Adler: Life, Literature, Legacy. Edited by Julia Creet, Sara R. Horowitz and Amira Bojadjija-Dan. Evanston: Northwestern University Press, pp. 273-301.

Wolff, Lynn L., ed. 2019. A Modernist in Exile: The International Reception of H. G. Adler (1910-1988). Cambridge: Modern Humanities Research Association. 